\section{文献}

1) Williams, P. C.: The Diagnosis and Conservative Management of the Lumbosacral Spine, in Lectures on Regional Orthopedic Surgery and Fundamental Orthopedic Problems. Vol. 4, 103, J. W. Edwards, 1948.

2) Pheasant, H. C. : Practical Posture Building,
Clin. Orthop. $25: 83,1962$.

3）石田肇・他：各種腰痛疾患に対する体操療法. 整形外科, $17: 516,1966$.

4) 村岡保徳: 腰痛対策について. 労働の科学, $21: 14,1966$.

5) Steindler, A., : Kinesiology of The Human Body. C. C. Thomas. 1955.

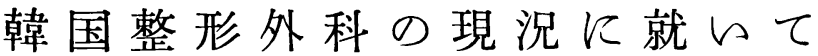

\author{
韓国全南大学医科大学 整形外科 \\ 教授禹済仁

\section{Present State of Orthopedic Surgery in Korea. Prof. Je In Woo}

By

Department of Orthopedic Surgery, School of Medicine, Chonnam National University, Korea

今回学会席上で, 韓国整形外科の現況に就いて, 会 員の皆様に御紹介の機会を得たことは，非常に身に余 る光栄である.

扱て，此のような広範囲な題目を，制限された時間 内で，紹介する事は本当に難しい問題あるので，極く 簡単に紹介したいと思う。

一般に整形外科が，目覚しい発展をきたしたのは， 皆様も御存じの通り，第二次世界大戦後であり，特 に, 韓国での整形外科が，一般外科加ら分離独立し て, 新しい学問として目覚しい発展をきたしたのは, 1950 年勃発した韓国動乱により戦争外科, 即ち災害 外科が急速に発達し始め, 比の方面の研究には, 先進 国の教えに従つて特別なる考慮と研究が必要である事 が，痛切に身近に迫り，其の結果，1956 年整形外科 学会の創立を見たのである.だから約 10 年の短い歷 史を持つているわけで，其の内容が，目立つて新しい 所があるのであなく，唯長い歴史を誇る他学会の業績 を, 熱心に追求, 或は臨床に応用する程度である. し かし時には, 韓国固有の, そして症例の比較的多い疾 患に対する診療方針には，多少とも差異がある事を指 摘したいのである.

1. 医科大学及び病院の実態に就いてみると，4つ の国立総合大学には，単科大学として，各々医科大学 があるのを始めとして，私立医科大学が $4 つ ， 今$ 年の
始めに新しい $2 つ の$, 私立医科大学が新設された. 以 上の医科大学のうち，9つの大学では, 全部が男女共 学であり, 其の外には女子医科大学が, 1 つあるので 全部で 10 の医科大学がある.

病院は, 前に述べた 10 の大学附属病院は勿論であ るが，その他には，Seoul 国立中央医療院を始めとし て, 数個の陸軍病院, 市立, 道立病院, そして鉱山附 属病院, 赤十字病院等があり, 大部分は完全なる設備 の下に充実した技術の training と診療の完壁をきた している，そして以上の病院には，国家で承認した整 形外科専門医が，整形外科患者の診療及び技術の指導 に，たずさわつて居り，大学病院に收容出来ず, 余つ ている若い医師達の training 屯受け持つている. 然 しながら, 大都市之か, これらの教育病院より遠い処 にある。保健所では，整形外科の専門医を，置いて いる処がなく，例え，おきたいと思つても，資格の 有る専門医数が足らない実情である。 そういうわけで Emergency Case の適切な治療が，他の何れの科よ り屯必要で, 整形外科 Case の予後に対して致命的な Handicap を招来するわけである. 其の解決策として, 患者の transportation の便宜をはかり, 保健所医師, 又は開業医で整形外科関する training を望む者に は, 年に 2 回招待して, 大学の staff 等が講義をし, 又年に 1 回各大学では, 希望する医師を求めて, 約一 
週間乃至 10日間, 各科にわたつて実際的臨床講義, 又は治療を見学させる等により，手遅れのないよう に, training をしている. それよりも専門医の数が 充分にふえて, 実際的に田舎行行つて, 直接診療にた ずさわる様にならなければならないと思つている。そ して，一般人にも整形外科が，一般外科の分科ではな く, 完全に独立した. そして全々 principle が違う学 問である事を認識させる様汇努力している，現在整形 外科を plastic 或は, cosmetic surgery 之誤認して 病院を迴る患者が, 相等多い現状である.

2）整形外科の発達としては, 学会創立以前では, 整形外科は一般外科の一分科として, 所謂四肢外科と いう名の下に, 講義されていた為に, 充実した専門的 教育は, 全然不可能であり, 顧られなかつた学問であ る事は事実であつた，私自身20年前の, 学生時代を顧 るに, 一般外科の講義が長びき, 四肢外科の講義で は, 各科各論で, 重要であるとてろだけ抜いて数時間 聞いただけであつた. 今の学生達は, 3 年から整形外 科のむつかしい講義を受けて policlinic. I. D. C. 臨休 講義で, たたきあげられ, 目の迴る位熱心に勉強しな ければならないし，1，2 年の時は, 解剖,生理, 3,4年 の時は, 整形外科で, 失敗すれば落第するという, 定 評のある重要な科目となつている。，一年の時の解剖の 講義が, Systemic Anatomy（系統解剖）であるの で, 3 年の時には, 整形外科の理解に, 大して助けに ならない点もあつて, 私の大学では一年の解剖の一部, 特に骨, 関節, 筋肉, 又は腱の部分は, 整形外科亡一 旦意見を交わした後, 生きた解剖を教えたいと思つて いる. 例えば整形外科の Resident training を終え, 専門医の資格を得た大学院生が, 解剖教室の助教に転 入しているが，てれらは，将来解剖と整形外科が一心 同体となつて指導をより効果的にしようとする動きと 思つている.

学会の動きに就いてみると, 1956 年 6 月 26 日創立. した整形外科学会は，独立.した年中行事が行われてい る. 其の席上では色々な theme が㗅議されるが, 前にも述べた様に，特に新しい部門が有るのではなく 大低は，追試等である。しかし私達は先進国と，有を 亚べようと努力している. 月に一度の集談会は, 中央 之地方別に各大学, 或は総合病院, 陸軍病院が, 順番 で主催しているが, 中央での集談会数は, 既に 105 回 に達している. 現学会々員は, 正会員と準会員の 2 つに分けられ，Intern 1 年を終えた医師達は, 準会
員に加入する事が出来, 整形外科 Resident 3 年の課 程を終えた時には, 学会の審査により, 正会員に加入 出来るのである. 正会員はすう 1 力年の Resident 課 程を終え, 所定の試験に合格した者に, 専門医の資格 が与えられるのである. 学会創立当時には, 10 名余り であつた会員が，現在では 110 名の正会員，165名の 準会員, 合わせて 275 名の会員を持つ学会に発展し, 毎年 40 50 名の新入会員がある. 他の科では Resident がなくて困つている所ああるが，整形外科では 余つて選択に困つている実情である. 此のように学会 が発展して来る一方, 今迄一般外科之共同で発刊して いた, 学会雑誌む不便な点が多く, 独立した雑誌の必 要性が高まり, 結局昨年 10 月に, 整形外科学会雑誌 の創刊号の発刊をみた. 以上でようやく完全なる学会 としての, 必要な条件を全部具備したつるりである が, 内容の充実した，そして他学会に誇る事の, 出来 る様になる為には，更に今後の努加が必要であると思 つている. 整形外科専門医として開業している医師 は，現在 10 名そこそこで，それも大部分が都市に集 結された感があるが, 其の点であ近い将来に到る処で 国民が適切なる整形外科診療を受けられる社会になる 様に, 吾々会員は勿論, 政府の後援が要求されてい る. 学会支会は, 各道に 3 力所あるが, 各地方別支会 の主催の下に, 月例集談会が行われている.

専門医制度は, 1959 年から保健社会部主管の下に, 毎年 $6 \sim 7$ 月に，筆記及び，実技試験を行い，70 点を 合格線として，資格を与えているが, Board member は大低アメリカで training を受けて州国し，大学で 講義している staff であるので, 合格するには相当努 力しなければならない. 合格率は, 60〜70\%である.

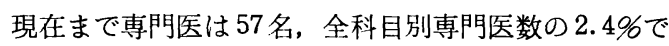
あり, それらの大部分が大学病院, 総合病院及び, 陸. 軍病院等に勤めているので, 開業医は前にも述べた様 に，10 名足らずである。一般に専門医制度があるこ とは必要であり,そして利点のみが多いとは, 言い難 いのであるが, Teaching Hospital の大学に於いて, 被教育者自身が漠然と，教育を受けるのではなく，4 年後には試験があることを意識して, より熱心に勉強 しているのを直接みていると, 専門医制度の必要性を 痛切に感ずる，大学又は Teaching Hospital での training に就いてみると, Resident は Intern を終 えて来た医師であるが, 4 力年の中, 始めの 2 力年は, 一般外科, 4 力月, 神経外科, 胸部外科, 各々 2 力月 
の training を受けなければならないし, 又 3 年の時 には, 麻酔科及びX-ray 科で, 各々 2 力月の training を受ける様に schedule を作つている.そして教育病 院内の各科には，専門医教育の認定を得た科加 Resident を受け入れる様, 許可されており, 毎年, 病院 信任会の審議会で, 調査して基準に足らなければ，認 定を取り消すことあある.

韓国での，国民保険制度はまだ実施されていない が，交通事故，鉱山及び炭鉱事故等が増えている関係 上, 自動車保険, 産災保険, 公務員, 療養制度等があ る. 先ず公務員は, 公務中の事故に対しては, 始めか ら終り迄，一切の診療に要する経費を国家で負担して いるので, 安心して働ける様になつている. 分婏に対 してもその経費の一部を, また公務以外の疾患に対し て屯診療費の一部を国家から支払つているので, 公務 員達は，非常な恩恵を受けている，次に自動車事故 は, 自動車保険会社により, 其の経費を支払うのであ るが, その最高負担額は $260 \$$ で, 若し其れ以上の治 療費に対しては，自動車会社自体が，責任を負うよう になつている，鉱山，工場等での事故に対しては，相 当に莫大な保障をしている，例えば paraplegia 患者 に対しては， 3 年も 4 年も入院して，手術 Recovery Reconvalescent 更に Rehabilitation 迄保障してくれ
る. 将来は全部の患者が保険により, 診療を保障され る様な，社会になる事が望ましく，そうなる事によ り, 災難, 事故や疾患に対しても経済的問題で患者が 心配する様な事はなく, 又医師も診療にのみ専心する 様になるのではないかと思つている.

最後に整形外科で, 取扱つている䓡患に就いては, 日木とはあらゆ点で共通しているので, 改めて紹介す る迄むないと思うが, 各大学病院での統計を簡単に上 げると，骨折が約 $1 / 3$, 炎症性疾患, 特に骨関節結核 力約 $1 / 3$ という割合である. 炎症性疾患中, 結核は春 椎, 又は関節の手術例が増える一方である. これはや はり，根治手術が，予後を良くし，治療期間を大変短 縮する為である. 又他の大学での研究内容は, 省略 するが, 私の大学では, 最近では, Ca. P. の metabolism に関して，興味を持つて研究をしており，特 に内分泌系統で, 最近 jounal に良くみられる thyrocalcitonia parathormone 等を追求している.

以上簡単に韓国の整形外科の現況に就いて, 述べ た.

私を此の学会に, 参席出来る様に直接招待し, 講演 の機会を下さつた宮城教授並びに本学会々員の諸先生 方に, 厚く感謝する.

\title{
Die Symptomatik der Lateralisation der Patella
}

\author{
Von \\ PROF. DR. MED. O. ROHLEDERER \\ Direktor der orthopädischen Univers. -Klinik, Kiel, Deutschland.
}

Bei der Routineuntersuchung des Kniegelenkes wird Kniekehle und Patellagleitweg oft vernachlässigt. Die Analyse des Patellagleitweges vermag jedoch Fälle unklarer Kniegegelenksbeschwerden ätiologisch richtig zu deuten.

Zunächst eine kurze normal-anatomische Einleitung. In der Norm (Abb. 1) üben Vastus medialis und lateralis einen symmetrischen Zug auf die Patella aus, der Knorpel des Patellagleitweges wird symmetrisch belastet. Bedingt durch die Form des lateralen Condylus beschreibt diese bei Beugung Streckung einen flachen medialkonvexen Bogen.

Jede Störung dieses Ablaufes (Add. 2), sei es durch Änderung der Achsenstellung oder Störung des Muskelgleichgewichtes, führt zu einer Æ̈nderung des Patellagleitweges und damit zu einem typischen klinischen Formbild, dem sogenannten Lateralisationssyndrom der Patella. 